УДК 37.378

DOI: $10.15330 /$ esu. 16.15-19
Тетяна Кучай,

доктор педагогічних наук, доцент,

Закарпатський угорський інститут ім. Ференца

Ракоці II (м. Берегово, Україна)

Tetiana Kuchai,

Doctor of pedagogical sciences, Associate Professor,

Transcarpathian Hungarian Institute. Ferenc Rakoki II

(Berehove, Ukraine)

tetyanna@ukr.net

Олександр Кучай,

доктор педагогічних наук, доцент,

Національний університет біоресурсів і

природокористування України (м. Київ, Україна)

Oleksandr Kuchai,

Doctor of pedagogical sciences, Associate Professor,

National University of Life and Environmental

Sciences of Ukraine (Kyiv, Ukraine)

kuchay@ukr.net

\title{
ЗАБЕЗПЕЧЕННЯ ЯКОСТІ ВИЩОЇ ОСВІТИ В ЄВРОПЕЙСЬКОМУ ОСВІТНЬОМУ ПРОСТОРI
}

\author{
PROVIDING QUALITY OF HIGHER EDUCATION IN THE EUROPEAN \\ EDUCATIONAL SPACE
}

У статті розглядається проблема якості вищої освіти в європейському освітньому просторі. Висвітлено засоби, які дозволять забезпечити реалізацію стратегії ЄС. Основним напрямком в інновачійному підході у внутрішньому функціонуванні вищої освіти с реформа навчальних програм та використания IКТ. Свропейські вищі навчальні заклади прагнуть досягти балансу між свойми інституиійними та академічними прагненнями та потребами у міжнародному співробітництві. Розкрито найтиповіиі моделі підготовки педагогічного персоналу в краӥнах Свропейського Союзу. Розглянуто завдання освіти 6 європейському просторі.

Ключові слова: вища освіта, університет, краӥни Свропейського Союзу, реформа.

The article deals with the problem of the quality of higher education in the European educational space. The tools that will ensure the implementation of the EU strategy are outlined. The main focus in the innovative approach to the internal functioning of higher education is the reform of curricula and the use of ICT. European higher education institutions seek to strike a balance between their institutional and academic aspirations and the need for international cooperation. The most typical models of teaching staff training in the countries of the European Union are revealed. The problem of education in the European space is considered.

One of the main tasks of the European higher education system is the establishment of a simplified procedure for access to higher education, which would strengthen Europe's position in the global market for higher education. In a number of European Union countries, quality assessment systems are not yet fully developed. Introduction of a convergent system of obtaining academic degrees leads to the need to have agreed criteria for assessing the quality and to establish a certain minimum requirements for educational levels. Therefore, the Bologna Initiative will have to bring accreditation issues into the center of the debate on higher education in Europe. As we see, the construction of the European Higher Education Area is a difficult process, but objectively necessary for the development of the entire system of modern higher education on our planet. The experience already gained from the Bologna process shows that it mobilizes the efforts 
of regional educational institutions aimed at integrating and expanding international cooperation, which provokes some optimism, even in those countries which have not yet joined the process, but are actively studying its experience and using its best. achievements in practice.

Key words: higher education, university, European Union countries, reform.

Постановка проблеми у загальному вигляді та її зв'язок із важливими науковими чи практичними завданнями. Сучасна освіта передбачає відкритість майбутньому, a iii подальший розвиток повинен спрямовуватися на подолання замкненості й надання освітньому процесу творчого характеру, що потребує нової освітньої моделі, яка б відповідала реаліям постіндустріального суспільства, тим глобальним змінам в усіх сферах життя, які викликані сучасними інформаційнокомунікаційними технологіями, стрімкими інтеграційними процесами в світі.

Вивчення міжнародного досвіду $є$ надзвичайно важливим для України, оскільки відсутність чіткої національної стратегії інтернаціоналізації освіти призводить до низького обсягу експорту освітніх послуг, незадовільних темпів розвитку міжнародних освітніх програм i, відповідно, ускладнює ефективну інтеграцію вітчизняної освіти до загальноєвропейського та світового освітнього простору [1].

Традиційні вищі навчальні заклади в Свропі також все більше усвідомлюють проблеми, пов'язані 3 новими видами вищої освіти, такими як корпоративні та віртуальні університети. У той же час, усвідомлюючи потреби вищих навчальних закладів у деяких країнах, що розвиваються, багато європейських університетів розпочали різні програми академічного співробітництва у партнерстві з ними. Саме в такому контексті європейські вищі навчальні заклади прагнуть досягти балансу між своїми інституційними та академічними прагненнями та потребами у міжнародному співробітництві та проблемами, що постають перед різними динамічними конкурентами по всьому світу [2].

Метою статті $€$ розкрити теоретичні засади якості вищої освіти в європейському освітньому просторі.

Аналіз останніх досліджень i публікацій, в яких започатковано розв'язання порушеної проблеми і на які спирається автор. Теорії та практиці освіти в країнах ЄС присвячені дослідження багатьох вітчизняних педагогівкомпаративістів, серед яких: А. Василюк, Л. Зязюн, Т. Кристопчук, О. Кузнєцова, Н. Лавриченко, М. Лещенко О. Локшина, О. Овчарук, О. Огієнко, Л. Пуховська, А. Сбруєва та інші.

Виклад основного матеріалу дослідження 3 повним обгрунтуванням одержаних наукових результатів. Свропейські освітні системи повинні поєднати в собі національні особливості разом 3 головним завданням - забезпечення модернізації методів оцінки підготовки студента, де основним замовником та оцінювачем є ринок праці, яке національний, так і регіональний (СС). До засобів, які дозволять забезпечити реалізацію даної стратегії відносимо наступні:

- використання ІКТ (інформаційно-комунікаційних систем);

- застосування ВОР (відкритих освітніх ресурсів), які повинні бути застосовані у всіх навчальних контекстах;

- системність у підвищенні педагогічної кваліфікації викладацького персоналу;

- зміцнення зв'язків між освітою і роботодавцями;

- застосування навчання на робочому місці; 
- запровадження нових стандартів щодо управління розвитком підприємництва в освіти;

- аналіз впливу ЄC на використання IKT i BOP в освіті. Застосування інформаційно-комунікаційних технологій (IКТ) передбачає набуття особою підприємницьких та громадянських навичок, що має фундаментальне значення для підготовки молоді до роботи на сучасному ринку.

Варто зазначити, що в європейських освітніх системах застосування IKT практикується формально в порівнянні 3 базовими навичками грамотності, математики та природничих наук. Частина проблеми лежить в складності оцінювання. Тільки 11 європейських країн (Болгарія, Естонія, Ірландія, Франція, Латвія, Литва, Мальта, Польща, Словенія, Фінляндія) мають стандартизовані процедури оцінки громадянських навичок, які спрямовані на розвиток критичного мислення та активної участі в житті суспільства. Оцінювання розвитку навичок підприємництва та ІКТ не існує взагалі в деяких країнах (Хорватія, Ісландія, Норвегія і Туреччина та ін.) [3].

Основним напрямком в інноваційному підході у внутрішньому функціонуванні вищої освіти є реформа навчальних програм та використання ІКТ. Сьогодні існує консенсус серед фахівців вищої освіти, щодо освітніх програм, які мають стати студенто-орієнтованими, а не навчально-орієнтованими. Такі зміни вимагають поглибленої реформи освітніх програм, більш активної участі студентів та використання IKT. Дворівневі структури навчання дозволяють запроваджувати гнучкі, індивідуальні та міждисциплінарні навчальні програми в освітньому процесі. Значення ступеня бакалавра як платформи, що дозволяє студенту змінити дисципліну, університет або країну, все більше визнається країнами ЄС [2].

Однією з проблем, що стоїть на порядку денному країн Європейського Союзу $€$ підвищення якості освіти. Між державами-членами країн $Є С$ в освітній галузі було підписано ряд важливих документів, серед яких “Arbeitsprogramm Allgemeine und berufliche Bildung 2010" ("Програма дій $з$ освіти і навчання 2010"), "Das Programm für Lebenslanges Lernen" ("Програма безперервного навчання"), а також "Strategischer Rahmen für die europäische Zusammenarbeit auf dem Gebiet der allgemeinen und beruflichen Bildung (ET 2020)" (“Стратегічні рамки європейського співробітництва в галузі освіти і навчання (ЕТ 2020)”). Свропейський Союз планує розширити свою діяльність на основі нових стратегічних планів, що охоплюють період до 2020 року. Основна спрямованість Європейського Союзу визначається стратегією "Європа 2020”. Зокрема, 12 травня 2009 року Рада міністрів освіти Свропейського Союзу в Брюсселі прийняла новий документ для стратегічного співробітництва в галузі освіти та підготовки кадрів на період до 2020 року "Strategischer Rahmen für die europäische Zusammenarbeit auf dem Gebiet der allgemeinen und beruflichen Bildung (ЕT 2020)". Цей документ визначає короткострокові пріоритети на період з 2009 до 2011 років, а також довгострокові завдання. У цьому документі виокремлено чотири стратегічні цілі: забезпечення безперервного навчання і мобільності; підвищення якості та ефективності освіти та підготовки кадрів; сприяння соціальній згуртованості, активній громадянській позиції; заохочення інновацій та творчості на всіх рівнях освіти і професійної підготовки [4].

Ханс Дьоберт визначає тенденції розвитку освіти в країнах Європи в таких площинах: порівняльний аспект, створення європейського простору, формулювання нових освітніх цілей, нові моделі управління, зміни у фінансуванні у галузі освіти, поєднання традиційних структур та нових медіа, багатомовність, розробка 
стандартів та контроль якості освіти, відкриття навчальних закладів. Системи освіти, зокрема, педагогічної у країнах Свропейського Союзу, не зважаючи на політичні та ідеологічні розбіжності діяльності різних урядів, зазнали на початку XXI століття загального руху до подальшої децентралізації та дерегулювання державного контролю [4].

Найтиповішими моделями педагогічної підготовки в країнах Європейського Союзу $є$ такі: паралельна модель, що будується за принципом паралельного вивчення всіх складових навчальної програми впродовж усього терміну підготовки вчителя; інтегрована модель, під час якої вивчення складових навчальної програми відбувається не тільки одночасно, а й у взаємозв'язку в певних темах та завдяки інтеграції теорії з практикою; послідовна модель, що передбачає вивчення загальних i спеціальних дисциплін на першому етапі навчання, a вивчення дисциплін психологопедагогічного циклу й навчальну практику - на другому, завершальному етапі. Серед варіантів послідовної моделі найбільшого поширення набула “цюріхська модель", за якою психологопедагогічна підготовка здійснюється раніше від вивчення спеціальних дисциплін і методик їх викладання. Запровадження у навчальний процес модульних програм підготовки 3 використанням навчальних планів за принципом циклічної структури призвело до збільшення кількості структурних модифікацій підготовки вчителів у країнах Західної Європи [4].

ЄС визнає, що освіта та професійне навчання $є$ життєво важливими для розвитку сучасного суспільства та економіки. Стратегія розвитку $С С$ наголошує на необхідності налагодження співпраці між усіма країнами в цьому напрямі, а також обміну знаннями між ними. Освіта $€$ пріоритетним напрямом для урядів усіх країнчленів СС, втім системи освіти в цих країнах дещо різняться. Сучасний світ вимагає від студентів - майбутніх спеціалістів та їхніх викладачів більше нових знань та навичок, вільного володіння іноземними мовами, досвіду міжкультурного спілкування. Розуміючи все це та визнаючи вищу освіту одним 3 пріоритетів своєї діяльності у межах співпраці 3 сусідніми та більш віддаленими країнами, Європейська Комісія розробляє і впроваджує нові та вдосконалює існуючі освітні програми, які дають змогу студентам і науковцям отримувати стипендії та гранти на подальше навчання і проведення досліджень у країнах Свропи. Завдяки цьому десятки тисяч викладачів, студентів та науковців щорічно навчаються, працюють та викладають у різних країнах світу в межах міжнародних академічних програм.

Важливість дослідження освітньої політики ЄС обумовлюється також безпосереднім сусідством України і СС та зростанням зацікавлення українського суспільства до можливостей та перспектив реалізації євроінтеграційних прагнень України на сучасному етапі та використання позитивної динаміки співробітництва в освітній сфері та перспектив запровадження Болонського процесу в Україні. Останнє розширення ЄС створило принципово нову ситуацію на Європейському континенті та наблизило кордони СС безпосередньо до кордонів України, що впливає як на відносини між Україною та $Є С$, так і на розвиток України загалом.

Завданням освіти в європейському контексті $\epsilon$ сприяння розвитку громадянської свідомості, що базується на таких цінностях, як солідарність, демократія, рівноправність і взаємоповага. Важливими елементами освіти є повага до культурної та етнічної ідентичності $\mathrm{i}$, водночас, боротьба 3 різними формами шовінізму та ксенофобії. Саме тому базовим елементом освітньої політики є вивчення іноземних мов і отримання знань про інші країни. Особливу увагу необхідно зосередити на транснаціональній співпраці між окремими системами освіти [5]. 
Висновки представленого у статті дослідження і перспективи подальших наукових розвідок із зазначеного напряму. Одним з основних завдань розвитку європейської системи вищої освіти $\epsilon$ заснування спрощеної процедури доступу до вищої освіти, яка зміцнила б позиції Європи на світовому ринку вищої освіти. У ряді країн Європейського союзу системи оцінки якості ще повністю не розроблені. Введення ж конвергентної системи отримання академічних ступенів веде до необхідності мати узгоджені критерії оцінки якості і до встановлення певного мінімуму вимог для освітніх рівнів. Тому Болонська ініціатива повинна буде ввести питання акредитації в центр дискусій про вищу освіту в Європі. Як бачимо, побудова європейського простору вищої освіти - процес непростий, але об'єктивно не обхідний для розвитку всісї системи сучасної вищої освіти на нашій планеті. Вже отриманий досвід Болонського процесу показує, що він мобілізує зусилля регіональних освітніх структур, спрямованих на інтеграцію i розширення міжнародного співробітництва, що вселяє певний оптимізм навіть в тих країнах, які сьогодні ще не приєдналися до цього процесу, але активно вивчають його досвід і використовують його кращі досягнення на практиці.

\section{Література}

1. Сисоєва С.О., Кристопчук Т.Є. Освітні системи країн Європейського Союзу: загальна характеристика : навчальний посібник / С.О. Сисоєва, Т.Є. Кристопчук; Київський університет імені Бориса Грінченка. - Рівне : Овід, 2012. -352 с.

2. Білецька В.В., Поляничко О.М., Комоцька О.С. Тенденції розвитку вищої освіти в країнах Європейського Союзу // "Молодий вчений”, - № 4.3 (56.3) квітень. - 2018 . - С 10-14

3. Миськів Л. І. Стан та перспективи реформування вищої освіти в Європейському Союзі // Український часопис міжнародного права. - № 1/ 2013. - С. 127-130.

4. Кристопчук Т. Є. Система педагогічної освіти в країнах Європейського Союзу: спільні та відмінні риси / Т. С. Кристопчук // Наукові праці [Чорноморського державного університету імені Петра Могили комплексу "Києво-Могилянська академія"]. Сер. : Педагогіка. - 2012. - Т. 209, Вип. 197. - С. 121-126.

5. Краєвська О. Освітня політика європейського союзу: становлення та механізми реалізації // Вісник Львівського університету. Серія міжнародні відносини. -2011.Випуск 28. - С. 53-65.

\section{References}

1. Sysoieva S.O., Krystopchuk T.Ie. Osvitni systemy krain Yevropeiskoho Soiuzu: zahalna kharakterystyka : navchalnyi posibnyk / S.O. Sysoieva, T.Ie. Krystopchuk; Kyivskyi universytet imeni Borysa Hrinchenka. - Rivne : Ovid, 2012. - 352 c

2. Biletska V.V., Polianychko O.M., Komotska O.S. Tendentsii rozvytku vyshchoi osvity v krainakh Yevropeiskoho Soiuzu // "Molodyi vchenyi". - № 4.3 (56.3) kviten. - 2018 . - S 10-14.

3. Myskiv L. I. Stan ta perspektyvy reformuvannia vyshchoi osvity v Yevropeiskomu Soiuzi // Ukrainskyi chasopys mizhnarodnoho prava. - № 1/2013. - S. 127-130.

4. Krystopchuk T. Ye. Systema pedahohichnoi osvity v krainakh Yevropeiskoho Soiuzu: spilni ta vidminni rysy / T. Ye. Krystopchuk // Naukovi pratsi [Chornomorskoho derzhavnoho universytetu imeni Petra Mohyly kompleksu "Kyievo-Mohylianska akademiia"]. Ser. : Pedahohika. - 2012. - T. 209, Vyp. 197. - S. 121-126.

5. Kraievska O. Osvitnia polityka yevropeiskoho soiuzu: stanovlennia ta mekhanizmy realizatsii // Visnyk Lvivskoho universytetu. Seriia mizhnarodni vidnosyny. -2011.Vypusk 28. - C. 53-65.

Одержано статтю: 12.06.2019

Прийнято до друку: 26.06.2019 